\title{
Visual Processing Assessment on Children: A Pilot Study
}

\author{
Atmarita* \\ SMP Negeri 4 Bolo, Bima, Indonesia \\ Syarifuddin \\ STKIP Bima, Bima, Indonesia
}

*Coresponding Author: atri.atmarita@gmail.com
Dikirim: 26-05-2021 ; Direvisi: 27-05-2021 ; Diterima: 28-05-2021

\begin{abstract}
Visual Processing skill plays a key role on how children learn in some areas, such as math, reading, writing and others. This skill supports a child's self-esteem in the areas of learning. The researcher aims to investigate the visual processing of a children on this age and see how visual processing works on the children. A children of 4.8 years old is the participant of the research. The researcher provide 3 kinds of visual processing assessment: visual discrimination, visual memory/visualization, and visual-motor integration. The first assessment shows that the children in this age recognized and well-discriminated the visual shapes provided. On the second assessment, he memorized where the specific shapes laid on, then he got the correct recognitions. Dealing with visual motor integration, he experienced the first puzzle and reflected on the second puzzle as he did the visual motor integration well. These visual assessments show that the visual processing in children is developing and becoming a significant variables of the children's preferences of learning physically and mentally.
\end{abstract}

Keywords: visual processing; visual assessment

\begin{abstract}
Abstrak: Keterampilan Pengolahan Visual memainkan peran kunci dalam bagaimana anakanak belajar di beberapa bidang, seperti matematika, membaca, menulis dan lain-lain. Keterampilan ini mendukung harga diri anak dalam bidang pembelajaran. Peneliti bertujuan untuk menyelidiki pemrosesan visual anak pada usia ini dan melihat bagaimana pemrosesan visual bekerja pada anak-anak tersebut. Seorang anak berusia 4,8 tahun adalah peserta penelitian. Peneliti memberikan 3 jenis penilaian pemrosesan visual: diskriminasi visual, memori visual / visualisasi, dan integrasi visual-motorik. Penilaian pertama menunjukkan bahwa anak-anak di usia ini mengenali dan membedakan dengan baik bentuk visual yang diberikan. Pada penilaian kedua, dia menghafal di mana letak bentuk tertentu, lalu dia melakukan pengenalan dengan benar. Berkaitan dengan integrasi motorik visual, ia menyusun gambar acak pertama dan merefleksikannya pada penyusunan gambar acak kedua saat ia melakukan integrasi motor visual dengan baik. Penilaian visual ini menunjukkan bahwa pemrosesan visual pada anak berkembang dan menjadi variabel yang signifikan dari preferensi belajar anak secara fisik dan mental.
\end{abstract}

Kata Kunci: pemrosesan visual; penilaian visual

\section{INTRODUCTION}

New Horizons Vision Therapy Center described that visual processing is the way human's brain works to interpret and make sense of what human sees in the world around him. Visual processing skills are needed in teaching and learning process. The students need the skill to learn better through their vision. The visual perceptual skill takes a huge place since the authentic materials around us can be processed through vision. In some extent, the students occupy more cognitive effort.

@ 2021 JPPI (https://bimaberilmu.com/jurnal/index.php/jppi) 
Whether it slows down or fastens up the learning process, it depends on how developed their visual processing skill is.

Visual Processing skill plays a key role on how children learns in some areas, such as math, reading, writing and others. This skill supports a child's self-esteem in the areas of learning. New Horizons Vision Therapy Center stated: "A child who has not developed good eye movement, eye teaming, and eye focusing skills will often have more difficulty with visual processing skills".

Davis, Pitchford \& Limback (2011) found the advance evidence in their study that from an early age, cognitive and motor development is linked by elucidating the underlying nature of this relationship. And furthermore, the results have important implications for clinical, educational, and experimental practices. Carlton (1992) stated that vision plays a number of roles in producing skilled movements. For instance, it can be seen in vision's relationship with performance, in which vision enables performance in aiming the object manually by specifying the position, indicating the position into movement plan, and providing alternative information due to the target and how to execute the movement plan.

The stage of this age is considered as the golden period in a human's development. Sesha (2013) explained that at this stage, the memory of the kid is very high because they can pick up or grasp anything easily and it provides the spaces for long-term memory to be developed through their intense attention and long duration of exposure. This stage is also called as development age. The kid tries harder to adjust himself to the world and its emotions. This is the stage where the child can understand, think and express his views. The researcher aims to investigate the visual processing of a children on this age and see how visual processing works on the children.

\section{LITERATURE REVIEW}

\section{Visual Processing}

Visual processing has been studied in depth due to its advantageous natures into human's life. Visual processing utilizes the main sense that is vision. The vision leads to many related impact to human's body, and the main impact is connection between vision and brain. The studies expanded this connection and shared so many significant findings. The most recent studies were dealing with visual processing relationship with mental workload at the office in Japan context (Wang et al, 2015) and the use of visual processing in driving assessment (Sun et al, 2018). Both studies shared the advantages of utilizing visual processing into visual-assessed field's needs.

Furthermore, the studies on visual processing expanded throughout many fields. Recently, the study on ball sports indicated that the discrimination of shot power was easily performed on the basis of early auditory visual information (Sors et al, 2017). As a physical respond to the visual-motor function, visual-motor training creates functional connections among visual and motor brain regions that reflect different aspects of handwriting experiences for children (Vinci-Booher, James, \& James, 2016). More to brain function, visual quantities are perceptually discriminated automatically and rapidly within the occipital cortex, in which the part of brain's main responsible is influencing mathematical ability (Guillaume et al, 2018). Thus, individual differences in visual recognition can play role in individual differences in 
intelligence (Zakharov et al, 2016). Moreover the education field, many studies resulted the significance of involving visual processing in the language learning activities, both traditionally and digitally (Tzuriel \& Eiboshitz, 1992; Dibek, 2012; Emam \& Kazem, 2014; Wang, Wu, \& Hsu, 2017).

\section{Visual Processing Assessment}

The skill can be both treated and strengthened with vision therapy, in which there are some visual perceptions areas can be tested on a visual information processing assessment. New Horizons Vision Therapy Center offered some of the assessment:

\section{Right/Left Knowledge \& Letter Reversals}

The Piaget Right/Left Awareness Test evaluates the understanding of laterality and directionality. For optimal visual processing, directional responses should be accurate and completely automatic. Delays in this area may result in difficulties reading and interpreting maps, directions and instructions.

The Gardner Reversals Frequency Test evaluates the ability to write, recognize and match letters and numbers in their correct orientation. Confusion in this area may result in reversals of letters such as "b" and " $d$ " and words such as "on" and "no" and "was" and "saw". It will also slow down the speed of fluency or reading and writing.

2. Visual Discrimination

The ability to recognize the differences and similarities between objects and images based on shape and size, it is important to be able to distinguish between different letters and words in order to read and write. An important step in developing this skill is teaching your child to pay attention to detail.

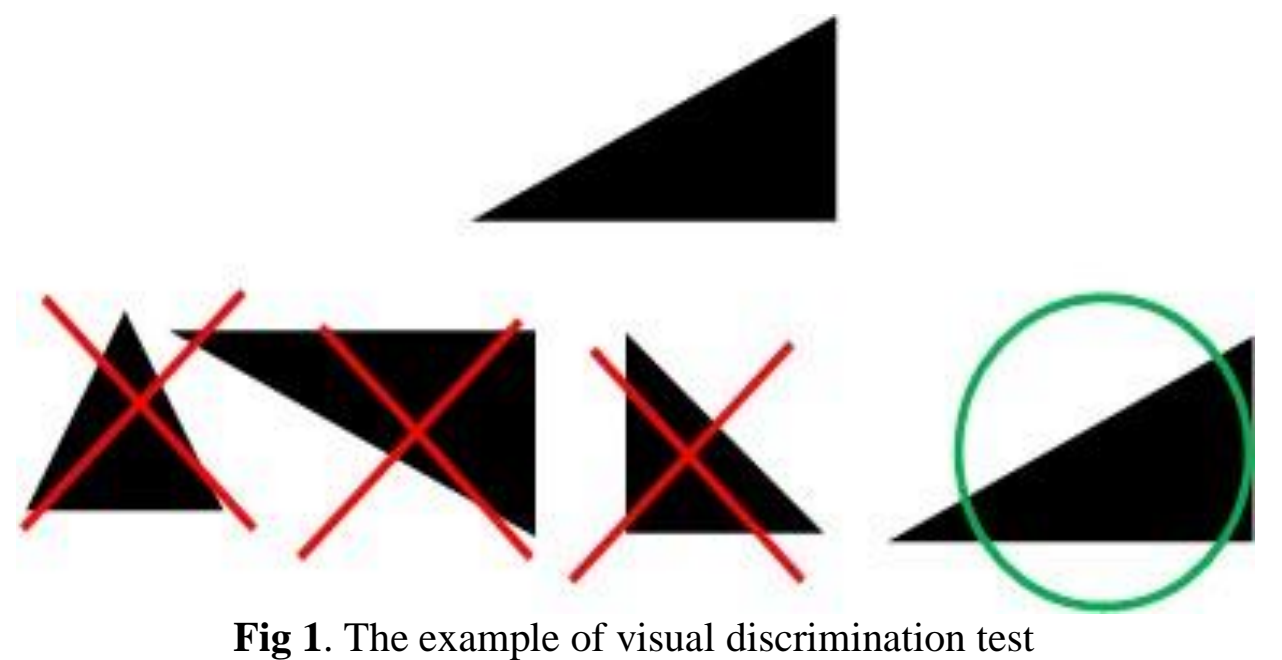

Which design is exactly like the one on top?

3. Visual Figure Ground

The ability to find and pick out the important information in a visually busy background, such as picking out numbers in a word problem. Difficulty can also lead to poor planning/organization.

@2021 JPPI (https://bimaberilmu.com/jurnal/index.php/jppi) 

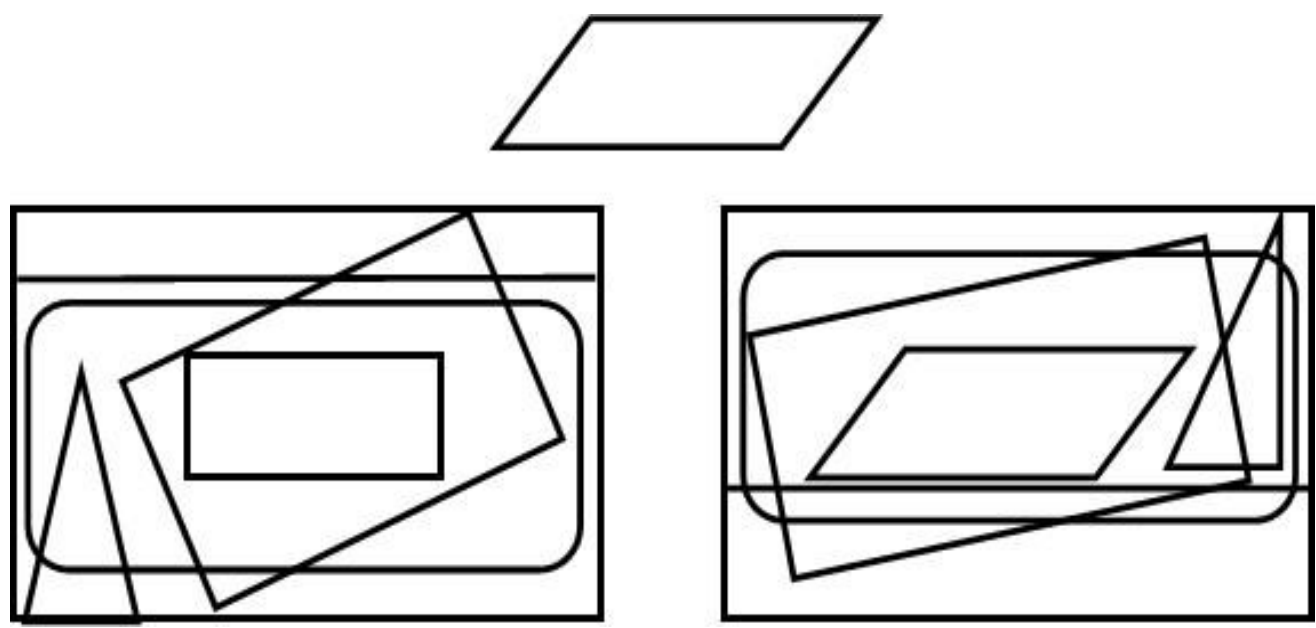

Fig 2. The example of visual figure ground test

The top shape is hidden in which picture?

4. Visual Closure

The ability to know what an image or object is when part of that image or object is missing. It is also the ability to quickly recognize differences in similar words to enable reading fluently. Difficulty can cause confusion of similar objects/words, and make it slow to complete tasks.
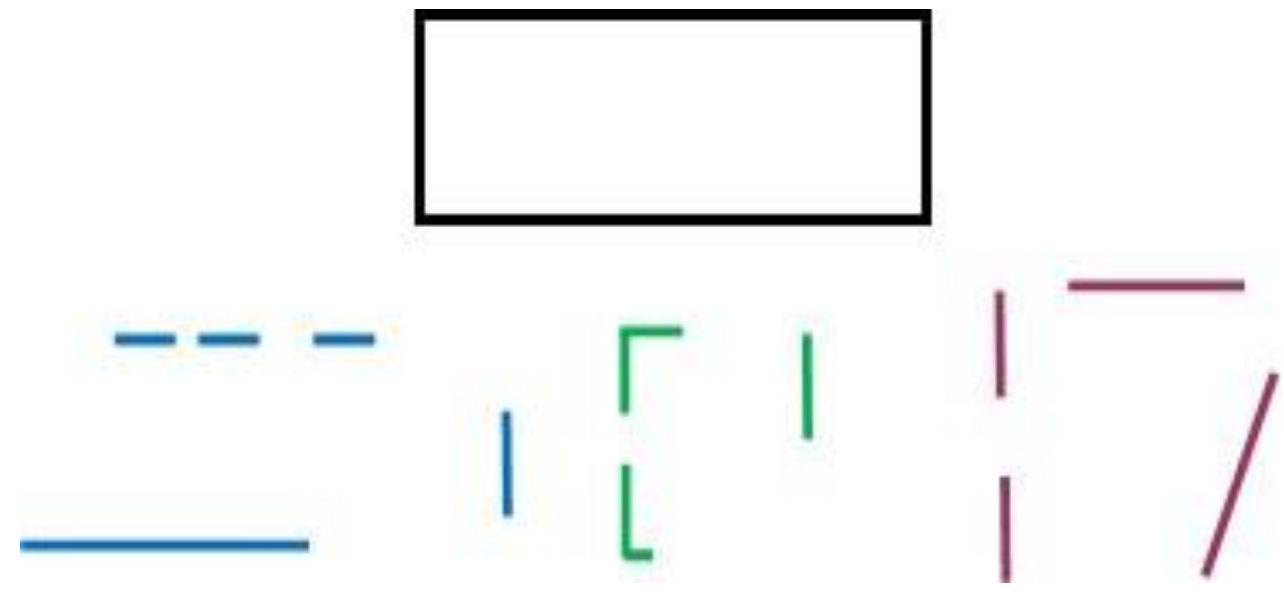

Fig 3. The example of visual closure test

If each design was completed and the lines were not moved, which one would look exactly like the design on the top?

\section{Visual Memory/Visualization}

The abilities to recall visual information over time and to accurately recall a sequence of shapes or objects in the correct order, these skills are important for spelling and writing. Difficulties lead to poor spelling, poor recall of information, and difficulty with remembering a sequence of directions, poor reading comprehension and difficulty with writing. 


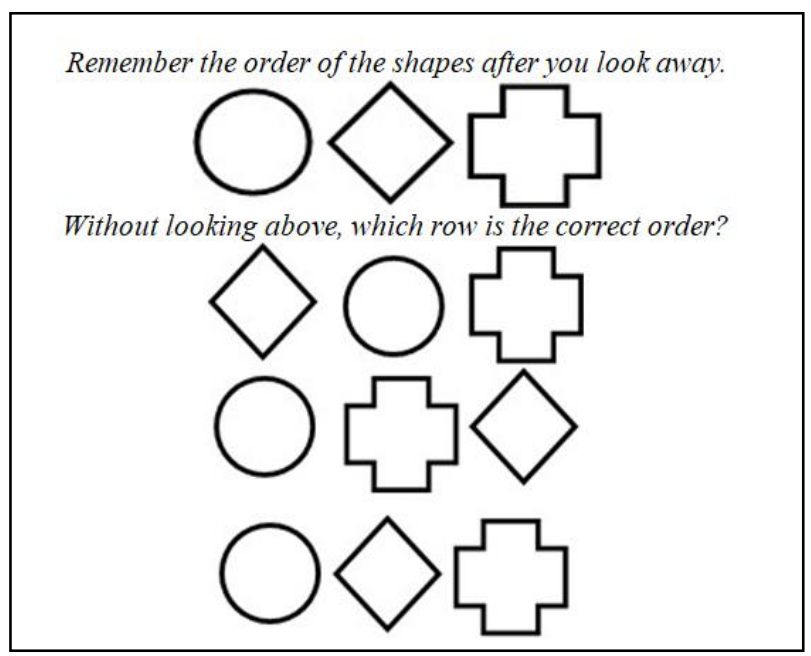

Fig 4. The example of visualization test

\section{Visual Motor Integration}

The Beery Developmental Test of Visual-Motor Integration evaluates visual form perception and reproduction. Efficient visual-motor integration supports optimal eye-hand coordination. A deficiency in visual-motor integration may result in increased difficulty with handwriting, copying from one place to another and reduced ability to express ideas in written form.

\section{Auditory-Visual Integration}

This is the ability to accurately relate an auditory sound with a visual symbol, or integrate what we hear with what we see. This skill relates to understanding phonics, reading music and reading fluency.

\section{METHOD}

\section{Participant}

A child of 4.8 years old was the participant of the research. The participant was taken based on the previous findings that the result of the research showed the tendencies of the children of the subject matters' mastery, such as: mathematics, spelling, reading and so forth.

The participant was a kindergarten student who was exposed to formal learning for over a year. At the school, he was provided with some particular visual processing assessment integrated with the subject matters. As the study was planned, the researcher took a preliminary study by testing him with some visual processing assessment of his student's worksheet from his school. The result of the study was used to select the visual processing assessments that were appropriate for him.

\section{Stimuli, apparatus, design and procedure}

The research occupied a case study on a single subject. As the literature review aforementioned, the visual processing assessment provided could be many. However, the appropriateness and level of difficulties should be considered. The children of kindergarten were taught to identify some visual processing assessment on their level of understanding. As the consequence, the researcher only provided 3 kinds of visual processing assessment. They were: visual discrimination, visual memory/visualization, and visual-motor integration. 
The research was conducted into one session only, in which it extended for 15 minutes for each trial. The research was recorded to support the analysis of the result.

The procedures of the study were designed as follows:

a. The participant was given the explanation about each trial before it was conducted.

b. The first trial was visual discrimination. The participant was asked to distinguish the pictures by their shapes.

c. The second trial was visual memory/visualization, in which the participant was asked to identify a group of visual shapes and colors. The assessment was modified by colors due to his development of colors' identification in his school.

d. The third trial was visual-motor integration. The participant was not welldeveloped in handwriting and drawing, as preliminary study resulted. Therefore, the researcher utilized two sets of simple wood puzzles to assess this visual processing.

e. The maximum time to identify the visual processing was 1 to 3 minutes. It was based on the findings of the previous researchers that the children's memory was abnormally high on their golden period. That was the reason to give a short-time identification.

Stake (2000) recommends data collection of case study in the following types of information: 1) the nature of the case, 2) its historical background, 3) the physical setting, 4) in some different contexts, 5) other cases through which this case is recognized, and 6) through those informants.

The data were analyzed due to misidentified pictures and time allotment for the trials in the recorded video. The result will be theoretically justified with the previous studies.

\section{RESULTS}

\section{Findings and Discussion}

The findings of this research showed that on the first trial, the participant recognized the visual assessment into two ways. The first, he recognized the shape of the visual assessment, in which visually he could point out the shape but could not name the shape because of his limited knowledge of shape's names. The second recognition was he knew the colors and mentioned them. It seems that he has learned about the colors in his school, that he told the researcher so. This assessment showed that the children in this age recognized and well-discriminated the visual shapes provided.

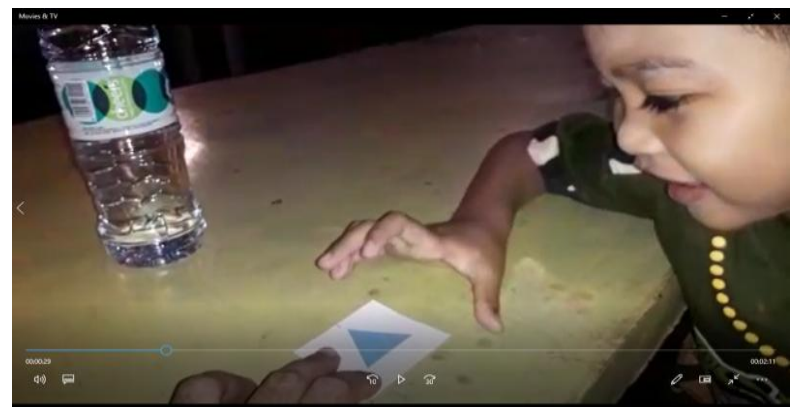

Fig 5. The visual shape recognition trial 
The next trial of visual processing was the visual memory or visualization. The level of difficulty was raised, in which the participant should recognized a group of different shapes and also the order of the shapes. The participant seems to be hesitated and made mistake at the first recognition. As he mentioned orally the name of the shapes, as he named it by himself, and memorized where the specific shapes laid on, then he got the correct next two recognitions. He exactly recognized and named the shape of "love", "triangle", and "circle".

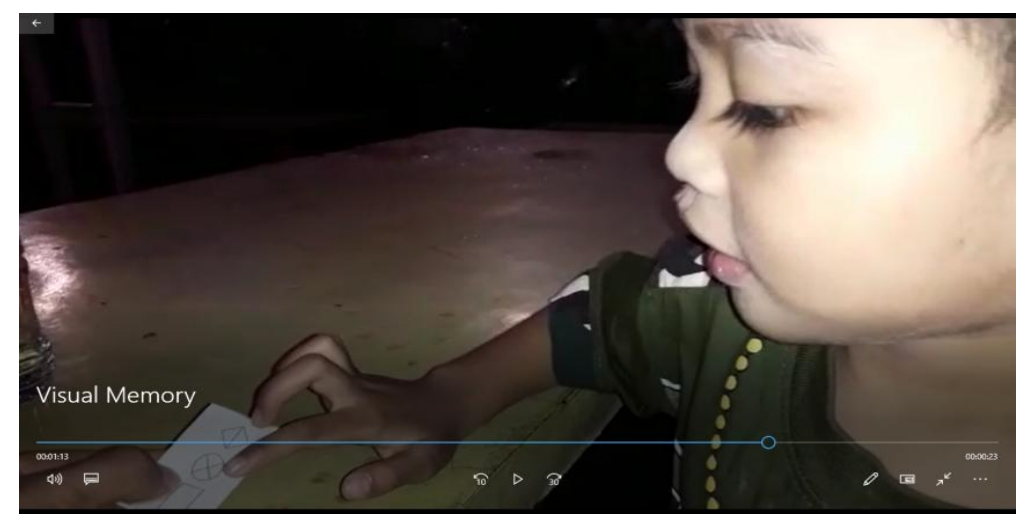

Fig 6. The visualization trial

The last trial was on visual-motor integration, in which the participant recognized the shape and put the appropriate ones on the right section. The participant was given two different puzzles. The first visual-motor assessment, the participant hesitated when he was given the unpacked puzzle. He asked for the initial gaze to the whole packed puzzles. However, he tried and failed at once and finally, he made up the puzzle on the right places. On the second assessment, the puzzle was more challenging for him. As he has the experience from the first assessment, he did the visual motor integration well.

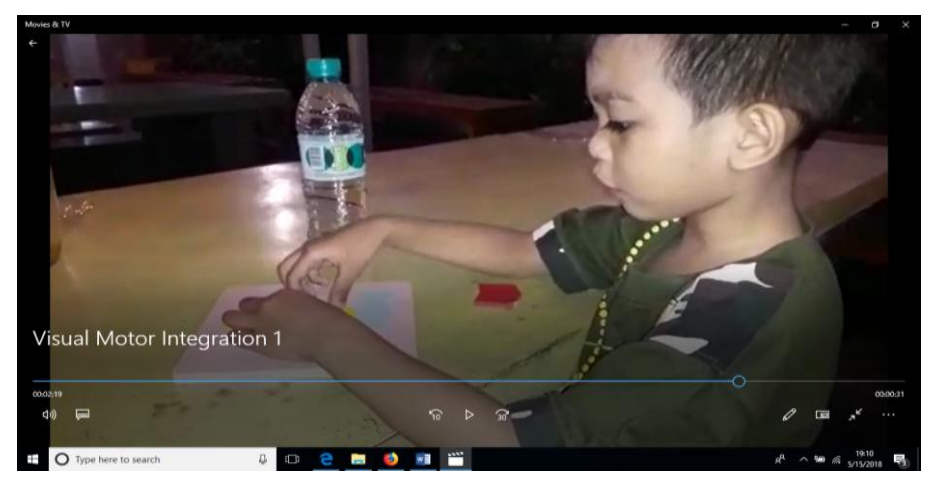

Fig 7. The visual-motor integration trial

The results of the research were in line with the previous findings. Bezrukikh \& Terebova (2009) analyzed the characteristic of visual perception (VP) in five- to seven-year-old children according to a modified method of Frostig, which estimated the following VP components: visual spatial perception, figure-ground differentiation, and visual motor integration. The finding was age dependence of the development of VP components indicating the variation of the rates of their development was found. All VP components rapidly developed between five and six 
years of age; considerable changes in visual motor integration and visual spatial perception were observed between six and seven years of age.

\section{CONCLUSIONS AND SUGGESTION}

The study was conducted in a very limited participation and also kinds of assessment. The next researcher may extent the study into larger number of participants and complete kinds of visual processing assessment. The other variables of visual processing should also be considered in order to achieve the validity and reliability values. The next researcher can also range the participants to older children or following the development stages to obtain a more significant and complete results.

\section{REFERENCES}

Bezrukikh, M.M.,\& Terebova, N.N. (2009). Characteristics of the development of visual perception in five- to seven-year old children. Human Physiology, Vol. 35, Issue 6, pp. $684-689$.

Davis, E.E., Pitchford, N.J., \& Limback E. (2011). The interrelation between cognitive and motor development in typically developing children aged $4-11$ years is underpinned by visual processing and fine motor control British Journal of Psychology (2011), 102, pp. 569 - 584.

Dibek, E. (2012). Implementation of visual motor ability enhancement program for 5 years old. Procedia Social and Behavioral Sciences 46 (2012), pp. 1924 - 1932.

Emam, M., \& Kazem, A. (2014). Visual motor integration in children with and without reading disabilities in Oman. Procedia Social and Behavioral Sciences 112 (2014), pp. $548-556$.

Guillaume, M., Mejias, S., Rossion, B., Dzhelyova, M., \& Schiltz, C. (2018). A rapid, objective and implicit measure of visual quantity discrimination. Neuropsychologia 111(2018), pp. 180 - 189.

Sesha (2013). Why childhood is the golden period of life. In http://www.indiastudychannel.com/resources/161191-Why-childhood-is-thegolden-period-of-life.aspx

Sors, F., Murgia, M., Santoro, I., Prpic, V., Galmonte, A., \& Agostini T. (2017). The contribution of early auditory and visual information to the discrimination of shot power in ball sports. Psychology of Sport and Exercise 31 (2017), pp. 44 51.

Stake, R.E. (2000). Case studies. In N.K. Denzin \& Y.S. Lincoln (Eds.), Handbook of qualitative research $\left(2^{\text {nd }}\right.$ ed., pp. $\left.435-454\right)$. Thousand Oaks, CA: Sage.

Sun, Q. C., Xia, J.C., He, J., Foster, J.,\& Falkmer, T. (2018). Towards unpacking older drivers' visual-motor coordination: A gaze-based integrated driving assessment. Accident Analysis and Prevention 113 (2018), pp. 85 - 96.

Tzuriel, D., \& Eiboshitz, Y. (1992). Structured program of Visual-motor integration (SP - VMI) for preschool children. Learning and Individual Differences Vol. 4 No. 2, pp. $103-124$.

http://www.newhorizonsvisiontherapy.com/what-is-visual-processing/ 
Vinci-Booher, S., James, T.W., \& James, K.H. (2016). Visual-motor functional connectivity in preschool children emerges after handwriting experience. Trends in Neuroscience and Education.

Wang, J., Ohtsuka, R., Yamanaka, K., Shioda, K., \& Kawakami, M. (2015). Relation between mental workload and visual information processing. Procedia Manufacturing 3 (2015), pp. 5308 -5312.

Zakharov, I.M., Voronin, I. A., Ismatullina, V.I., \& Malykh, S.B. (2016). The relationship between visual recognition memory and intelligence. Procedia Social and Behavioral Sciences 233 (2016), pp. 313 - 317. 